Article

\title{
Roadmap for Valuing Soil Ecosystem Services to Inform Multi-Level Decision-Making in Agriculture
}

\author{
Mark V. Brady 1,2,*®D, Jordan Hristov ${ }^{2,3}$, Fredrik Wilhelmsson ${ }^{4}$ and Katarina Hedlund ${ }^{2,5}$ \\ 1 AgriFood Economics Centre, Department of Economics, Swedish University of Agricultural Sciences (SLU), \\ 22007 Lund, Sweden \\ 2 Centre for Environmental and Climate Research (CEC), Lund University, 22362 Lund, Sweden; \\ jordan.hristov@ec.europa.eu (J.H.); katarina.hedlund@biol.lu.se (K.H.) \\ 3 European Commission, Joint Research Centre (JRC), 41092 Seville, Spain \\ 4 AgriFood Economics Centre, Lund University, 22007 Lund, Sweden; fredrik.wilhelmsson@agrifood.lu.se \\ 5 Department of Biology, Lund University, 22362 Lund, Sweden \\ * Correspondence: mark.brady@slu.se
}

Received: 31 May 2019; Accepted: 23 September 2019; Published: 25 September 2019

\begin{abstract}
Agricultural soils contribute to human welfare through their generation of manifold ecosystem services such as food security, water quality and climate regulation, but these are degraded by common farming practices. We have developed a roadmap for evaluating the contribution of both private- and public-good ecosystem services generated by agricultural soils to societal welfare. The approach considers the needs of decision-makers at different levels, from farmers to policy-makers. This we achieve through combining production functions-to quantify the impacts of alternative management practices on agricultural productivity and soil ecosystem services-with non-market valuation of changes in public-good ecosystem services and benefit-cost analysis. The results show that the net present value to society of implementing soil-friendly measures are substantial, but negative for farmers in our study region. Although we apply our roadmap to an intensive farming region in Sweden, we believe our results have broad applicability, because farmers do not usually account for the value of public-good ecosystem services. We therefore conclude that market outcomes are not likely to be generating optimal levels of soil ecosystem services from society's perspective. Innovative governance institutions are needed to resolve this market failure to safeguard the welfare of future generations.
\end{abstract}

Keywords: natural capital; soil carbon; policy; valuation; climate change; food security; nutrient retention; benefit-cost analysis

\section{Introduction}

Well-functioning agricultural soils, in addition to provisioning ecosystem services such as food, fiber and biofuels, generate a range of regulating and supporting ecosystem services that are crucial for agriculture particularly [1] and human welfare generally [2]. These include climate regulation, water quality, nutrient cycling, and control of crop pests and diseases; and cultural services such as biodiversity, spiritual values, recreation and knowledge [3].

Intensification of agricultural production over recent decades has had profound negative impacts on both the levels of ecosystem services generated by soils and their resilience $[4,5]$. This is undermining agricultural productivity [6], accelerating climate change [7] and contributing to water pollution [8]. An important driver of this development is that farmers' production decisions tend to be based on relatively short-term analyses that fail to capture the impacts of soil management practices on soil natural capital and associated regulating and supporting ecosystem services that underpin crop 
yields [9]. Another important driver is that farmers are not likely to be accounting for the value of public-good services such as carbon storage in their production decisions, because providing public goods can be costly to them while the benefits are enjoyed by society generally [10].

For these reasons there is a pressing need for methods to evaluate the long-term effects of farmers' choices of soil management practices on societal welfare generally and the sustainability of agricultural production particularly [11,12]. If we are to safeguard agricultural soils for future generations, the diverse benefits provided by these to humanity need to be accounted for at relevant levels of decision making; from individual farmers who actually manage soils, to regional administrators and national policymakers acting in the interests of society [13].

Despite the growing recognition of the centrality of soil ecosystem services to human welfare and sustainable development [14], very few studies have tried to link gradual changes in soil health or quality brought about by different agricultural management practices, to impacts on human wellbeing generally. By this we mean the impact of declining soil health on societal welfare, as a consequence of reduced flows of soil ecosystem services [15]. Historically, the literature has focused on evaluating the costs to society of the complete loss or physical destruction of soils due to erosion [16]. Emerging studies are deepening our understanding of how soils benefit society by conceptualizing soils as a complex natural capital that underpins the generation of manifold ecosystem services, and not just crop yields $[17,18]$.

Choices of farming practices can have profound impacts on soil ecosystem services such as carbon storage $[19,20]$. So far, studies attempting to value the contribution of soils to societal welfare are either partial, in that they determine the value of different levels of supporting and regulating ecosystem services to a particular group within society, e.g., farmers [21], or focus on valuing a particular soil species, e.g., earthworms [22]; or on valuing the total stock of soil natural capital in a particular place $[23,24]$. Novel approaches are therefore needed that make it possible to evaluate the desirability of alternative soil management practices from society's perspective, which requires valuing their impacts on both private- and public-good ecosystem services [25].

We aim to quantify and evaluate the impact on societal welfare of changes in soil natural capital and associated ecosystem services brought about by different agricultural management practices. To do this we develop a roadmap for valuing the long-term impacts of different practices on the welfare of farmers in particular and society in general, to inform multi-level decision-making. Such an evaluation can inform decision makers of the potential welfare gains of allocating scarce resources to the conservation of soil natural capital in socially desirable quantities.

The purpose of our roadmap is to provide decision support at relevant management scales. Crucially, we focus on valuing changes in stocks of soil natural capital and concomitant levels of soil ecosystem services, so-called marginal valuation, because this is the information that is relevant for evaluating the consequences of a particular decision [28]. In other words, to answer the question: how will a farmer's and society's welfare be affected if an alternative practice is chosen? Consequently, we focus on changes in flows of ecosystem services. From this perspective, monetary valuation of changes in services, as we apply in our roadmap, is an indicator of the amount of income that society would be willing to give up (i.e., willing-to-pay) to obtain an additional unit of a particular service without becoming worse off [29]. Market prices of agricultural products have this characteristic, but as we shall show, approximations based on the same principle can also be found for public-good services that do not have market prices [30]. Thereby we hope also to improve understanding of the utility of valuing changes in flows of ecosystem services for improving the management of soils for the common good.

To illustrate our roadmap, we apply it to an intensive arable cropping region in Sweden. In addition to crop production, we include in the analysis three public-good ecosystem services that are affected by choices of agricultural practices: (i) carbon sequestration and green-house gas abatement that mitigate climate change; (ii) nutrient retention that improves water quality; and (iii) soil productivity as a basis for future food security. The specific conservation measure or alternative practice we evaluate is the inclusion of different proportions of a perennial grass in the typical arable crop rotation in the region, 
which otherwise comprises only annual crops, because grass can effectively rejuvenate soil ecosystem services in the region $[26,27]$. We proceed by introducing the study region and describing the three different method-steps comprising the roadmap. Thereafter we present the results from our study region and conclude with a discussion.

\section{Materials and Methods}

The first method step is applied at the farm level to quantify and value the impacts of changes in soil natural capital on agricultural productivity (i.e., fertilizer needs and yields) and farmers' welfare (profits) respectively. In the second step we quantify the aggregate impacts of alternative management practices on soil natural capital and levels of public-good ecosystem services at the regional level (e.g., county) using simulation. Decisions are usually made at this level to implement policy schemes that are adapted to local conditions. In the third step, we value and aggregate impacts at the national level using benefit-cost analysis. It is at this level that policies can be implemented for maximizing the societal benefits of soils, such as providing incentives for provisioning public-good ecosystem services (or alternatively minimizing negative environmental impacts of agriculture).

\subsection{Case-Study Region}

The study region is known as Götalands södra slättbygder or GSS and is one of Sweden's eight naturally defined agricultural regions. Production conditions within the region are relatively homogeneous and agricultural land-use dominates the landscape. Accordingly, fields are generally large, open and well connected with farm centers. It is characterized by high yields and specialized arable farming using intensive production practices. The standard yields and nitrogen fertilizer input rates are respectively given for the four main crops: (a) winter wheat, $7900 \mathrm{~kg} \mathrm{ha}^{-1}$ and $160 \mathrm{~kg} \mathrm{~N} \mathrm{ha}^{-1}$; (b) spring barley, $5700 \mathrm{~kg} \mathrm{ha}^{-1}$ and $91 \mathrm{~kg} \mathrm{~N} \mathrm{ha}^{-1}$; (c) winter rapeseed, $3600 \mathrm{~kg} \mathrm{ha}^{-1}$ and $172 \mathrm{~kg} \mathrm{~N} \mathrm{ha}^{-1}$; and (d) sugar beet, $60,000 \mathrm{~kg} \mathrm{ha}^{-1}$ and $120 \mathrm{~kg} \mathrm{~N}^{-1}$ [31]. For comparison the average spring barley yield in Sweden is $4306 \mathrm{~kg} \mathrm{ha}^{-1}$, but yields are as low as $2336 \mathrm{~kg} \mathrm{ha}^{-1}$ in the far north [31].

Due to the long history of intensive arable cropping and lack of organic matter inputs to the soil such as application of stable manure, soil organic carbon (SOC) content is relatively low compared to bordering regions where livestock production and perennial grass crops dominate (Figure 1a). Nevertheless, the highest standard yields in Sweden are also found in the GSS region because of the higher overall productivity of soils (Figure 1b).
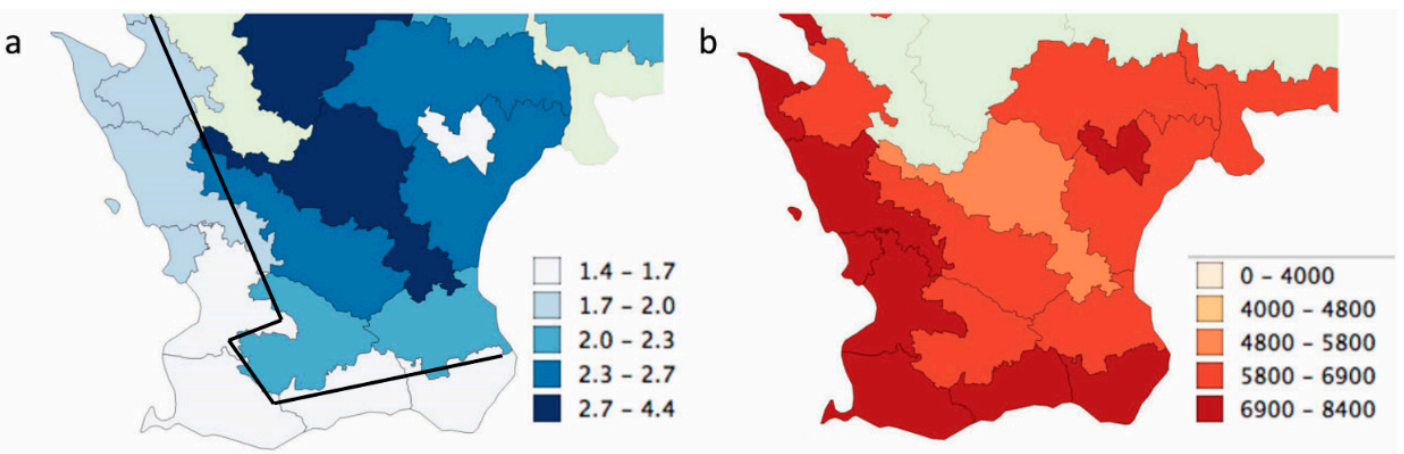

Figure 1. Comparison of (a) soil organic carbon (SOC) content $(\% \mathrm{C})$ and (b) standard yields of winter wheat $\left(\mathrm{kg} \mathrm{ha}^{-1}\right)$ by yield-survey districts in the county of Scania in southern Sweden. The Götalands södra slättbygder (GSS) region is to the left and below the black lines in panel (a). Sources: Panel (a) is based on soil organic matter measurements taken from almost 90,000 soil samples from arable fields across Scania as part of The Rural Economy and Agricultural Societies consultancy services to farmers [32] and panel (b) on Standard Yields by Survey District [31].

Average SOC content in arable fields across GSS is $1.7 \%$ SOC based on measurements covering $33 \%$ of the arable area in the region (Table S1). Some 50 years ago the soils in GSS had SOC content 
in the range $2.7-4.4 \%$ SOC [19], which implies that intensive arable cropping practices have resulted in declining SOC content. It is therefore estimated that SOC content declines at an annual rate of $0.5 \%$ relative to the preceding year if additional conservation measures are not taken. Our underlying assumption in the coming simulations is that all farms in the region are managed using conventional practices and no particular measures are taken to maintain soil carbon, other than incorporation of harvest residues in the soil through ploughing. A relative increase of $1 \%$ per annum is assumed to be possible if a multi-year grass fallow is included in the normal rotation of annual cash crops [33-36].

\subsection{Farm-Level}

The first step towards improving soil management decisions is quantifying how different management practices are likely to impact soils and their functioning from a farmer's perspective. A production function relates quantities of output of a production process to quantities of inputs. These functions can be simple mathematical functions or even complex simulation models, as long as they can quantify the relationships among flows of ecosystem services, land use, and inputs of purchased and natural or unpriced inputs [37]. Once a production function is defined, farmers' implicit valuation of supporting soil ecosystem services and underlying natural capital can be derived from market prices of crops and manufactured inputs [38].

\subsubsection{Estimation of Agri-Ecological Production Functions}

To quantify the impacts of changes in flows of supporting ecosystem services on agricultural productivity, we used the following quadratic production (or yield response) function for each of the crops studied [19]:

$$
Y(C, N)=a_{1}+a_{2} N+a_{3} N^{2}+a_{4} C+a_{5} C^{2}+a_{6} N C
$$

where $Y$ is yield $\left(\mathrm{kg} \mathrm{ha}^{-1}\right), N$ is total input of mineral and plant-available nitrogen in manure $\left(\mathrm{kg} \mathrm{N} \mathrm{ha}^{-1}\right)$, and $C$ is SOC content in the topsoil in percent. An important difference between the variables is that farmers choose $N$ directly, whereas $C$ is determined indirectly through their historical choices of soil management practices. Accordingly, farmers cannot influence $C$ in the short-run while $N$ can be applied according to needs.

\subsubsection{Farmers' Profit Maximization Problem}

The estimated agri-ecological production functions can then be used to determine the implications of changes in supporting ecosystem services on agricultural productivity, i.e., maximum yield and optimal fertilizer input rates, and thereafter farmers' profits.

A farmer's short-term decision problem is about maximizing their profit given the current level of supporting ecosystem services, which we denote $\bar{C}$. If we replace the variable $C$ in Equation (1) with $\bar{C}$ and let $p$ be the product price and $w$ the unit cost of applying fertilizer $N$, while other costs are assumed to be constant, then the farmer's short-term profit maximization problem for a particular unit of land can be formulated as:

$$
\pi_{\max }(N \mid \bar{C})=\max _{N} p Y(N \mid \bar{C})-w N .
$$

Since the production function is assumed to be concave then the profit function will also be concave, and the maximum short-term profit is defined by the following first-order condition:

$$
\frac{\partial \pi}{\partial N}=p\left(a_{2}+2 a_{3} N+a_{6} \bar{C}\right)-w=0
$$

From Equation (3) it follows that the optimal input of fertilizer, $N^{*}$, given SOC content $\bar{C}$ is:

$$
N^{*}=\frac{w-p\left(a_{2}+a_{6} \bar{C}\right)}{2 a_{3} p}
$$


which implies that an increase in $C$ will result in a reduction in the optimal fertilizer $N$ input if $a_{6}<0$ [19]; likewise, a decrease in $C$ will result in an increase in $N$.

Finally, the optimal yield is found by inserting $\bar{C}$ and $N^{*}$ in the production function, Equation (1), giving:

$$
Y^{*}=a_{1}+a_{2} N^{*}+a_{3}\left(N^{*}\right)^{2}+a_{4} \bar{C}+a_{5} \bar{C}^{2}+a_{6} N^{*} \bar{C} .
$$

Equation (5) implies that $N$ and $C$ can substitute for each other, but not completely, hence lower $C$ will result in a lower profit, and vice versa.

These equations can then be used to evaluate the impacts of changes in supporting services brought about by alternative soil management practices on yields, optimal fertilizer input and farm profits.

\subsubsection{Marginal Value of Supporting Soil Ecosystem Services}

To determine the impact of a marginal change in flows of supporting soil ecosystem services on the farmer's maximum profit, one simply differentiates the optimized value of Equation (2), known as the value function and denoted here $\pi^{*}$, with regard to $\bar{C}$ (by the Envelope theorem). After plugging in $N^{*}$ this implies $\pi^{*}=p Y(N * \mid \bar{C})-w N *$, and

$$
\Delta \pi^{*}=\frac{\partial \pi^{*}}{\partial \bar{C}}=p\left(a_{4}+2 a_{5} \bar{C}+a_{6} N^{*}\right)
$$

Now, given that supporting ecosystem system services are generated by an underlying stock of soil natural capital, it follows that the implied change in the value of the farmer's stock of natural capital is the present value of the change in the stream of maximum future profits $\Delta \pi^{*}$ defined by Equation (6), which for an infinite future is:

$$
\mathrm{PV}=\Delta \pi^{*} \sum_{i=0}^{\infty} \frac{1}{(1+\delta)^{i}}=\frac{\Delta \pi^{*}(1+\delta)}{\delta},
$$

where $\delta$ is the discount rate and $i$ the period. The discount rate reflects the farmer's preferences over the future, i.e., models to what extent they would be willing to trade-off a smaller profit today to realize a larger profit in the future. The higher the discount rate, the lower their implied valuation of future profits. Explanations for discounting include that the future is uncertain (one might not live long enough to realize a future benefit or that the benefit might not materialize) and that people are impatient [39].

The annuity defined by Equation (7) is defined over an infinite time horizon because land that is managed sustainably has an infinite lifetime. Since discounting reduces the current value of future profits, those profits arriving in the distant future will asymptotically decline to zero.

\subsection{Regional Level}

To simulate impacts on agricultural production and public-good ecosystem services of the alternative soil management scenarios at the regional level, we applied the agent-based AgriPoliS model of agricultural structures [40,41]. Through its capacity to model multiple ecosystem services [42] we adapted it for the purposes of this study, using the indicators of public-good services described below. In this way we developed public-good production functions based on simulation.

\subsubsection{Simulating Impacts on Ecosystem Services with the AgriPoliS Model}

AgriPoliS is an empirical agent-based model comprising a population of heterogeneous farm-agents (farmers) that compete for agricultural land in a dynamic and spatial environment in a defined region (see [43] for details). The study region (GSS) was based on a selection of typical farms from data on real farms and scaled up to represent the entire population of farms in the region [44]. These typical farms are heterogeneous in terms of size and production activities (primarily specialized 
crop farms and some livestock farms), but also other characteristics are considered such as the location of fields, field size, soil type and field-specific SOC content (the average \%SOC for the region and its standard deviation (Table S1) were used to randomly allocate SOC content to individual fields in our model landscape). Together with the modelled production activities, these characteristics define the landscape in which farms are embedded.

Through a mathematical programming approach, each farm-agent maximizes their income by optimizing their production activities, investments, and allocation of family labor and capital. Through integrating production functions for the main arable crops according to Equation (1) in AgriPoliS it can simulate the impacts of changes in SOC content on yields, variable input use and farm profits over time. The underlying assumption is that farm-agents optimize $\mathrm{N}$ input given the current SOC content of a field according to Equation (4), and that inputs of $\mathrm{P}$ and $\mathrm{K}$ are proportional to the optimal $\mathrm{N}$ input (based on Liebig's law of the minimum to ensure that the necessary balance is maintained between the nutrients), while pesticides and variable energy are a function of crop-specific yields. Consequently, AgriPoliS makes it possible to simulate the impacts of farmers' soil management decisions at a micro and spatially explicit level, which is crucial for studying impacts of farmers' land-use decisions on public-good ecosystem services as well as their use of potentially environmentally damaging inputs, specifically nutrients, pesticides and energy. The model also considers the impacts of different crop choices and soil management practices on SOC content at the plot level.

\subsubsection{Climate Mitigation through Carbon Storage and Reduced Green House Gas Emissions}

The public-good service climate regulation as modelled here has two components. First, changes in SOC content imply that concentrations of carbon dioxide in the atmosphere, and hence global warming potential, will change proportionally with the amount of carbon stored in the soil. The amount of carbon stored in the soil is a function of SOC content (\%SOC) and soil characteristics. It is approximated as:

$$
\text { C_store }=\text { SOC } \times(1-\text { STONES }) \times \text { soil_bulk_density } \times \text { soil_volume, }
$$

where SOC and STONES are the proportions of $C$ (i.e., \%SOC/100), and stones and gravel in the topsoil, respectively, soil_bulk_density is the weight of a particular volume of the top soil $\left(\mathrm{kg} \mathrm{dm}^{-3}\right)$ and soil_volume is the volume of soil in one ha of land measured to a particular depth $\left(\mathrm{dm}^{-3}\right)$. For calculating the current $C$ stock in the study region, we used the previously determined average $\% \mathrm{SOC}$ in the topsoil, thus SOC was set to 0.0171 (Table S1). For STONES and soil_bulk_density we used the average stone content and soil density across the five representative long-term experimental (LTE) sites used to estimate the production functions, which were 0.08 and $1.59 \mathrm{~kg} \mathrm{dm}^{-3}$, respectively (Table S5). Since farming primarily affects the topsoil through ploughing, which is done to a depth of $15-25 \mathrm{~cm}$ in the region, we calculated $C$ stock to a depth of $30 \mathrm{~cm}$, with resultant volume of soil in one ha of land being $3 \times 10^{6} \mathrm{dm}^{-3}$. Thus current $C$ stock in the region is, according to Equation (8) and the assumed parameter values: $C_{-}$store $=0.0171 \times(1-0.08) \times 1.59 \times\left(3 \times 10^{6}\right)=75,042 \mathrm{~kg} \mathrm{ha}^{-1}$ or $75.0 \mathrm{t} \mathrm{ha}^{-1}$, which is comparable to the average $C$ stock of $81.4 \mathrm{t} \mathrm{ha}^{-1}$ for the five LTE sites.

Second, the production of mineral $\mathrm{N}$ fertilizers causes substantial emissions of GHG, hence any change in farmers' demand for $\mathrm{N}$ fertilizers due to changes in supporting ecosystem services, will also have implications for the climate. In this study, we restrict our evaluation to emissions generated during fertilizer production, thereby ignoring potential emissions from application (which can be substantial but very uncertain). The production of $1 \mathrm{~kg} \mathrm{~N}$ for the Swedish market is assumed to result in the emission of $3.39 \mathrm{~kg} \mathrm{CO}_{2} \mathrm{e}$ [45].

\subsubsection{Water Quality Improvement through Nutrient Retention}

As a change in supporting ecosystem services affects agricultural productivity, it will indirectly affect water quality through nutrient retention. In particular, the choice of crop and fertilizer input rate 
influence the rate of leaching from arable land. For instance, a multi-year grass crop has a substantially higher nitrogen retention capacity than annual crops (Table 1).

A change in the rate of $\mathrm{N}$ fertilizer application has the potential to impact $\mathrm{N}$ emissions to the Baltic Sea due to its influence on nutrient leaching from arable fields [46]. An increase in the fertilizer input rate is likely to increase leaching and vice versa. To link AgriPoliS results for a particular crop $i$, unit of land $j$ and period $t$ to $\mathrm{N}$ emissions to the Baltic Sea, $e_{i, j, t}$, we apply the following model developed by Simmelsgaard and Djurhuus [47] for southern Scandinavian conditions:

$$
e_{i, j, t}\left(N_{i, j, t} \mid \bar{N}_{i, j, 0}, \bar{C}_{j, t}\right)=\bar{e}_{i, j} \times \exp \left[\beta_{j}\left(\frac{N_{i, j, t}-\bar{N}_{i, j, 0}}{\bar{N}_{i, j, 0}}\right)\right] \times R,
$$

where $\bar{N}_{i, j, 0}$ is the current optimal (or normal) rate of $N$ input to crop $i$ on field $j$ given current SOC content in the field, $\bar{C}_{j, 0} ; N_{i, j, t}$ is a new optimal $N$ input to crop $i$ on field $j$ given a new SOC content $\bar{C}_{j, t}$ in period $t$ per Equation (4); $\bar{e}_{i, j}$ is the normal amount of leached $N$ from crop $i$ on field $j$ given normal $N$ input; $\beta_{j}$ is the leaching potential of soil type $j$; and $R$ the average proportion of leached $N$ that actually reaches the Baltic Sea from arable fields in the region due to retention processes in waterways. The function was parameterized with crop-specific data for the study region according to Table 1 and the associated references.

Table 1. Crop-specific parameters for nitrogen emissions to the Baltic Sea.

\begin{tabular}{cccc}
\hline Crop & $\overline{\boldsymbol{e}}^{\mathbf{1}}$ & $\boldsymbol{\beta}^{\mathbf{2}}$ & $\boldsymbol{R}^{\mathbf{3}}$ \\
\hline Winter wheat & 37 & 0.71 & 0.75 \\
Spring barley & 42 & 0.71 & 0.75 \\
Winter rapeseed & 54 & 0.71 & 0.75 \\
Sugar beet & 26 & 0.71 & 0.75 \\
Multi-year grass fallow & 17 & n/a & 0.75
\end{tabular}

Sources: The study region corresponds to the Swedish leaching region 1a (Läckageregion) and associated parameter values: ${ }^{1}$ normal crop leaching rate from arable land [48] (Table 4.1 for a sandy-loam soil); ${ }^{2}$ soil-related leaching potential [49]; and ${ }^{3}$ retention in waterways during transport to the Baltic Sea is assumed to be $25 \%$, but could be as low as $10 \%$, implying a conservative assumption about this factor [50] (p. 34).

\subsubsection{Future Food Security through Conservation of Soil Productivity}

Conservation of soil natural capital contributes to food security because it is a necessary input to agriculture [51]. This implies that any changes in the productivity of agriculture related to changes in soil natural capital needs to be considered in an evaluation of societal welfare, because it reflects a change in the capacity of the soil to feed future generations [52]. In order to value changes in the underlying stock of natural capital we assume that the stock's value, as with financial assets such as shares and bonds, depends on expected future profits. Following from Equation (2), we denote $\pi_{t}^{*}\left(N_{t}^{*} \mid \bar{C}_{t}\right)$ as the expected average profit in the region in period $t$ given supporting ecosystem services $\bar{C}_{t}$ and optimal fertilizer input $N_{t}^{*}$. Assuming that land has an infinite lifetime, the implied change in the average value of the stock of soil natural capital per ha in year $T$ is therefore:

$$
\Delta N C_{T}=\frac{\pi^{*}\left(N_{T}^{*} \mid \bar{C}_{T}\right)}{\delta}-\frac{\pi^{*}\left(N_{0}^{*} \mid \bar{C}_{0}\right)}{\delta}=\frac{\pi_{T}^{*}-\pi_{0}^{*}}{\delta},
$$

where $t=0$ is the current period and $t=T$ denotes some finite period in the future, and $\delta$ is the social discount rate. In words, Equation (10) calculates the difference between two annuities in period $T$; that based on current maximum profit per ha and maximum profit at the end of the evaluation period (which in our study is $T=20$ ). Note that in the ensuing benefit-cost analysis $\Delta N C_{T}$ must be converted to its current value which we show below. 
To determine the total change in the value of soil natural capital in the region in period $T$ one need only multiply $\Delta N C_{T}$ by the area of agricultural land (given that $\Delta \mathrm{NC}_{\mathrm{T}}$ represents the average change in value per ha). In our simulations with AgriPoliS, $\pi^{*}$ is optimized for each individual farm in the model landscape, and thereafter the change in the value of the stock of natural capital is calculated based on the average profit per ha according to Equation (10).

\subsection{National Level}

The valuation of public-good ecosystem services is challenging, because these lack market prices as a source of objective marginal values. Instead one can turn to nonmarket valuation techniques that infer the value of changes in public-good ecosystem services from observing behavior on a related market, eliciting preferences through surveys or experiments [30] or preferences reflected in political decision-making [53]. For instance, the marginal value of carbon storage in soils could be derived from the potential damage costs of climate change [54] or the pricing of carbon through environmental taxes [55], and that of nutrient retention from citizens' willingness-to-pay to improve water quality [56]. The societal costs of provisioning public-good ecosystem services on the other hand are more straightforward to determine, as these are farmers' costs (e.g., reduced current yield) of increasing public-good services beyond what is optimal for them.

To evaluate the effects of the alternative management scenarios on societal welfare we first derive marginal values of the public-good ecosystem services and thereafter the formula for aggregating multiple welfare impacts to the societal or national level. These valuations are based, as far as possible, on Swedish citizens' preferences, to be consistent with principles of welfare economic analysis at the national level.

\subsubsection{Marginal Values of Public-Good Ecosystem Services}

In order to compare potential changes in private- and public-good ecosystem services we derived marginal values of the public-good services using results of relevant nonmarket valuation studies. Further, we assume that the potential changes in private- and public-good services would not be sufficient to influence market prices (Sweden is a small country) or the derived marginal valuations of public-good services. In this respect, we illustrate the principles of economic valuation for informing policymaking, but do not answer the question as to what the optimal area of a particular measure would be. Values of agricultural outputs (provisioning ecosystem services) and inputs are based on expected market prices [57], which is also the appropriate valuation basis from society's perspective. The price of $\mathrm{N}$ fertilizer as represented in Equation (2) reflects the cost of applying a compound fertilizer with appropriate fractions of the nutrients $\mathrm{N}, \mathrm{P}$ and $\mathrm{K}$.

The Swedish parliament has responded to the threats posed by climate change by legislating a carbon tax on petrol at $113 € \mathrm{t}^{-1} \mathrm{CO}_{2} \mathrm{e}$ [55] (the Swedish tax rate of $1180 \mathrm{SEK} \mathrm{t}^{-1} \mathrm{CO}_{2} \mathrm{e}$ was converted to Euros using the exchange rate of $10.40 \mathrm{SEK} / €$ as at 20190204). Since this tax rate has emerged from the Swedish parliament as a product of political deliberation, it can be argued that it reflects citizens' preferences [58]. Although relatively high, it is in the vicinity of the range of rates that have previously been estimated for a globally optimal carbon tax of $46-230 € \mathrm{t}^{-1} \mathrm{CO}_{2} \mathrm{e}[54,59]$ (the original rates of US $\$ 40$ to US $\$ 200$ per $\mathrm{CCO}_{2 \mathrm{e}}$ were converted to Euros using the exchange rate $0.87 \mathrm{US} \$ / €$ as at 20190204). Consequently, we adopt the tax rate set by the Swedish parliament as our high marginal value to Swedish citizens of climate regulation services, i.e., $113 € \mathrm{t}^{-1} \mathrm{CO}_{2} \mathrm{e}$. However, since this valuation is uncertain, we also test a low valuation based on the price of $\mathrm{CO}_{2}$ e emissions permits under the EU's emissions trading system, EU-ETS, of $6 € \mathrm{t}^{-1} \mathrm{CO}_{2} \mathrm{e}$ [60].

A major environmental problem related to nutrient emissions from agricultural land to water in the region is eutrophication of the Baltic Sea [61]. Retention of nutrients by Swedish soils provides therefore an ecosystem service in the form of better water quality. Ahlvik and Ahtiainen [62] (p. 13) have derived marginal values of changes in Baltic Sea water quality. Since our study area is in southern Sweden, we adopt their estimate of $11,460 € \mathrm{t}^{-1} \mathrm{~N}$ for improvements for the Baltic Sea Proper Basin from 
its current poor state, as our high valuation of the marginal benefits to Swedish citizens of improving water quality. To test the sensitivity of the results to this valuation we also test a low valuation of $270 € \mathrm{t}^{-1} \mathrm{~N}$ based on Swedish citizens willingness-to-pay assuming that good water quality has been achieved [62].

\subsubsection{Calculating Changes in Societal Welfare}

To evaluate the net impact of different soil management practices on societal welfare $(\Delta \mathrm{SW})$ we apply the principles of benefit-cost analysis (BCA), whereby a net present value is calculated over the evaluation period that considers both the impacts on farmers and public-good services:

$$
\Delta \mathrm{SW}=\sum_{j=1}^{J} \mathrm{PV}_{j}+\sum_{t=0}^{T} \frac{\mathrm{SEQ}_{t}+\mathrm{RET}_{t}+\mathrm{FERT}_{t}}{(1+\delta)^{t}}+\frac{\Delta N C_{T}}{(1+\delta)^{T}},
$$

where $P V_{j}$ is the economic impact on farmer $j$ in the population of $J$ farmers over the evaluation period $T$ according to Equation (7); $\mathrm{SEQ}_{t}$ is the change in the value of carbon sequestration services, $\mathrm{RET}_{t}$ is the change in nutrient retention services, and $\mathrm{FERT}_{t}$ is the change in GHG emissions from the production of mineral fertilizer, all in period $t$; and the last term containing $\triangle N C$ is the present value of the change in soil natural capital (future food security) according to Equation (10). Importantly Equation (11) takes into account peoples' time preferences through the discount rate $\delta$, bearing in mind that benefits occurring in the future are less valuable than a benefit occurring today. We apply a standard social rate of discount used in Sweden of 3.5\% [63]. For comparison, the standard discount (interest) rate used for normal investment decisions by farmers in the study region is 7\% [57].

Note that we calculate the change in the value of soil natural capital from society's perspective only (by applying a social rate of discount). Based on the premises of this study we assume that farmers are not aware of potential changes in their soil capital due to the adoption of the alternative management scenarios, because they currently lack information about the impacts of changes in supporting ecosystem services on their profits. Otherwise one could decompose $\Delta \mathrm{NC}$ into a portion affecting farmers' wealth by applying a private rate of discount, and another portion reflecting any additional value attributable to society having a lower rate of discount than farmers.

\section{Results}

Three alternative management scenarios were tested, these being three different proportions of grass cover in the crop rotation: $5 \%, 15 \%$ and $25 \%$ of the area sown to annual crops. The highest proportion of grass in the rotation is approximately that required in organic agriculture to provide green manure in the absence of livestock manure to meet crop nitrogen needs. The grass ley is therefore assumed to be a part of the crop rotation and maintained for two years in the same field.

\subsection{Farm Level}

The effects of a change in supporting ecosystem services (as related to a change in SOC content) on agricultural productivity were quantified with the quadratic production function specified in Equation (1), where the crop-specific parameter values can be found in Table S2. The production function for winter wheat (Figure 2a) shows the possible yields given current average SOC content of $1.7 \%$ in the region (Table $\mathrm{S} 1$ ) for increasing $\mathrm{N}$ fertilizer rates; and those for scenarios with an assumed higher $(2.1 \%)$ and lower content $(1.4 \%)$. Yield increases in response to higher SOC content and/or fertilizer input rates, but the effects are diminishing since additional increments in SOC or fertilizer give progressively smaller increments in yield (Equation (4)). As a result, the marginal revenue earned by farmers for increasing fertilizer input is declining (Figure 2b). The optimal N-rate given a particular SOC content, as defined in Equation (4), occurs when the marginal revenue of applying an additional $\mathrm{kg}$ of fertilizer is equal to its cost (i.e., where the relevant marginal revenue curve intersects the line Price_N in Figure 2b, which denotes the constant marginal cost of applying fertilizer). The optimal 
yield increases and the associated $\mathrm{N}$ rate decreases with higher SOC content, because of the implied increase in supporting ecosystem services. Consequently, higher flows of supporting services imply a higher gross margin for farmers, all other things being equal, because they can produce higher yields with lower inputs of costly mineral fertilizers.

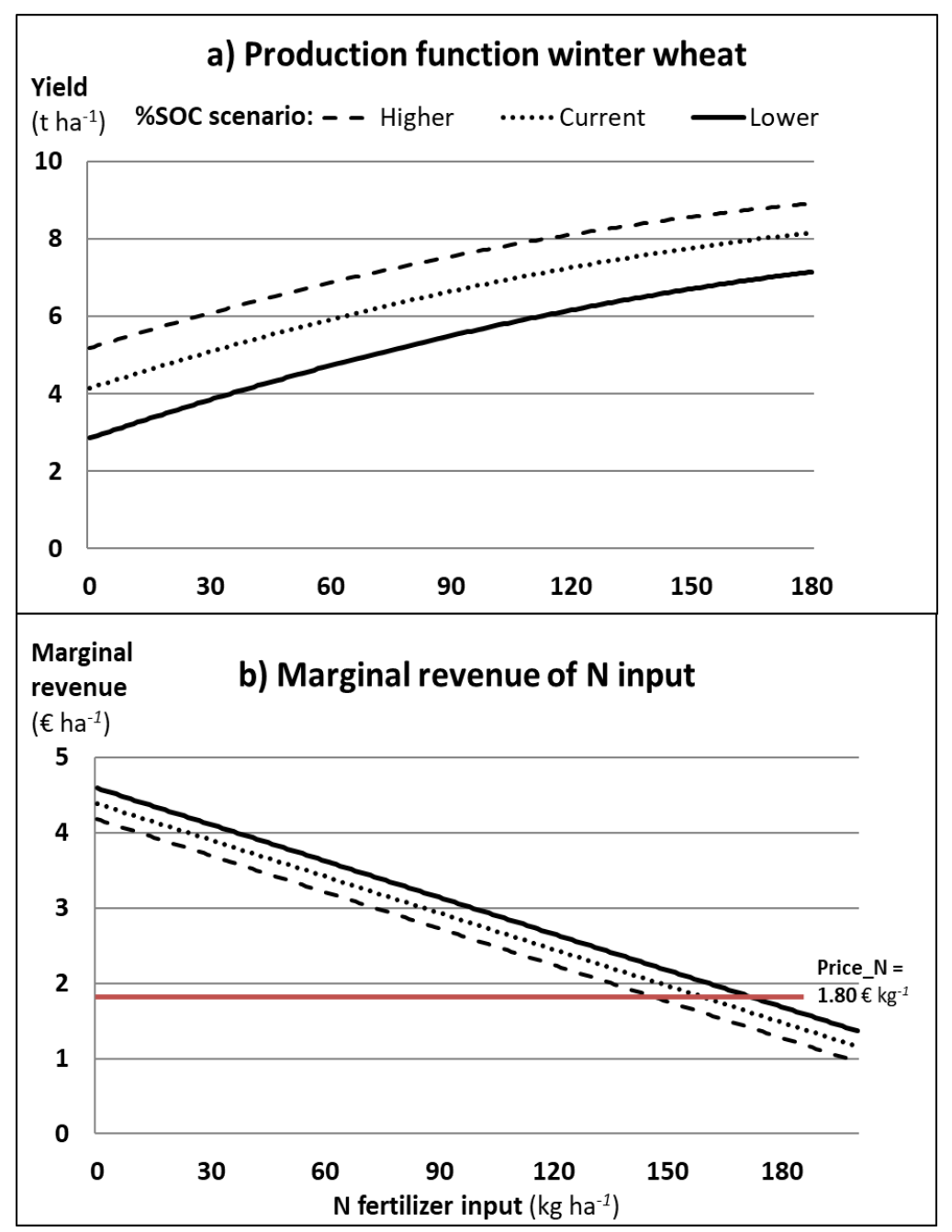

Figure 2. The winter wheat (a) production function for different SOC content scenarios, current (1.7\%), higher $(2.1 \%)$ and lower (1.4\%); and (b) associated marginal revenue functions calibrated to the standard yield $\left(7.9 \mathrm{t} \mathrm{ha}^{-1}\right)$ and optimal fertilizer rate $\left(160 \mathrm{~kg} \mathrm{~N} \mathrm{ha}^{-1}\right)$ for the current average SOC content in the study region (i.e., $1.7 \%$ SOC) and cost of applying fertilizer in the region (Price_N).

Note that the economic optimal yield is not the maximum yield, but that generating the maximum profit. This is because achieving the maximum yield generates higher costs then revenues on the margin, and hence from an economic perspective would be inefficient.

After integrating the estimated production functions for each crop with the farmers' parameterized profit function, Equation (2), using the price and cost data detailed in Table S6, the impacts of a marginal change in flows of supporting services on standard yield, fertilizer rate, and gross-margin for each crop and the average farm in the study region were derived (Table 2, Figure S1). 
Table 2. Impacts in the following year of a 1\% relative reduction in SOC content from the current level $(\% \mathrm{SOC}=1.7)$ for the average farm in the study region.

\begin{tabular}{|c|c|c|c|c|c|c|}
\hline \multirow{2}{*}{ Crop } & Yield & Fertilizer & GM & $\Delta$ Yield & $\Delta$ Fert & $\Delta \mathrm{GM}$ \\
\hline & $\left(\mathrm{kg} \mathrm{ha}^{-1}\right)$ & $\left(\mathrm{kg} \mathrm{ha}^{-1}\right)$ & $\left(€\right.$ ha $\left.^{-1}\right)$ & $\left(\mathrm{kg} \mathrm{ha}^{-1}\right)$ & $\left(\mathrm{kg} \mathrm{ha}^{-1}\right)$ & $\left(€\right.$ ha $\left.^{-1}\right)$ \\
\hline Winter Wheat & 7900 & 160 & 752 & -33.74 & 0.58 & -5.50 \\
\hline Spring Barley & 5700 & 91 & 421 & -10.87 & 0.29 & -1.64 \\
\hline Winter Rapeseed & 3600 & 172 & 707 & -47.91 & 0 & -14.00 \\
\hline Sugar Beet & 60,000 & 120 & 2538 & -318.43 & 1.96 & -13.47 \\
\hline Average per farm & $\mathrm{n} / \mathrm{a}$ & 141 & 841 & $\mathrm{n} / \mathrm{a}$ & 0.56 & -6.60 \\
\hline
\end{tabular}

Our simulations with the farm-level model predict that an annual 1\% relative increase in the stock of soil natural capital over a period of 20 years would result in an $18 \%$ increase in the average farm's gross margin. Conversely, a $1 \%$ annual decline in the stock would reduce farm gross margin by $20 \%$. Clearly, the long-term impacts of (dis)investing in soil natural capital are substantial compared to the short-term impacts, which are small. So small, in fact, that they are unlikely to be detectable by the famer from one year to another, because these changes are smaller than the normal variation between years due to the weather.

The results show that a reduction in supporting ecosystem services can be partially compensated by increasing fertilizer rates, but not fully, since maximum yield is always lower for lower SOC content (Figure 2a). As a result, a decline in supporting services will impact profit through changes in yields and fertilizer costs.

To quantify the long-term impact of a change in supporting ecosystem services on farmers' welfare one needs to determine the impact on the value of their stock of soil natural capital. Given that we have quantified the impacts of a change in supporting ecosystem services on yields, optimal fertilizer input and crop gross margins, we can value the implicit change in the value of their soil natural capital, by plugging the annual change in average farm gross margin of $6.60 € \mathrm{ha}^{-1}$ (Table 2) into Equation (7) for various rates of discount. As shown in Figure 3, if farmers were to degrade supporting services in the current year, as indicated by a one-off relative reduction in SOC content by $1 \%$ compared to the current level, then the implicit value of their soil natural capital will, on average, decline by a little over $200 € \mathrm{ha}^{-1}$ if they discount the future at $3.5 \%$ (i.e., the net present value of the annual reduction in future profits by $6.60 € \mathrm{ha}^{-1}$ ). This implies that it would be worthwhile for them to invest up to $\sim 200 € \mathrm{ha}^{-1}$ in the current year to avoid a $1 \%$ reduction in SOC content if they discount the future at $3.5 \%$. Alternatively, if they pay less regard to the future, as indicated by a $7 \%$ discount rate, then they would only be motivated in investing $\sim 100 € \mathrm{ha}^{-1}$ to maintain their stock of soil natural capital and attendant soil ecosystem services.

These valuations of changes in soil natural capital represent the change in the farmers' wealth, and hence welfare, resulting from the predicted changes in flows of supporting ecosystem services. Recall that the discount rate reflects the farmer's subjective valuation of or preferences over future benefits. The lower the farmer's regard for the future, as indicted by the higher discount rates, the less they will value changes in their soil natural capital. Given that farmers' generally discount the future at higher rates than the social rate of discount, which we assume is $2 \%$, then farmers' valuations of changes in soil natural capital will be lower than that for society, resulting in an intertemporal externality. That is, even if farmers have perfect information about the impacts of different practices on the value of their natural capital, they will most likely conserve lower stocks than desirable from society's perspective, because they apply higher discount rates (typically $7 \%$ in the region) than the social rate of discount. Consequently, farmers' preferences over the future have profound implications for their management of soil natural capital, as conceptualized in the seemingly innocuous choice of discount rate. 


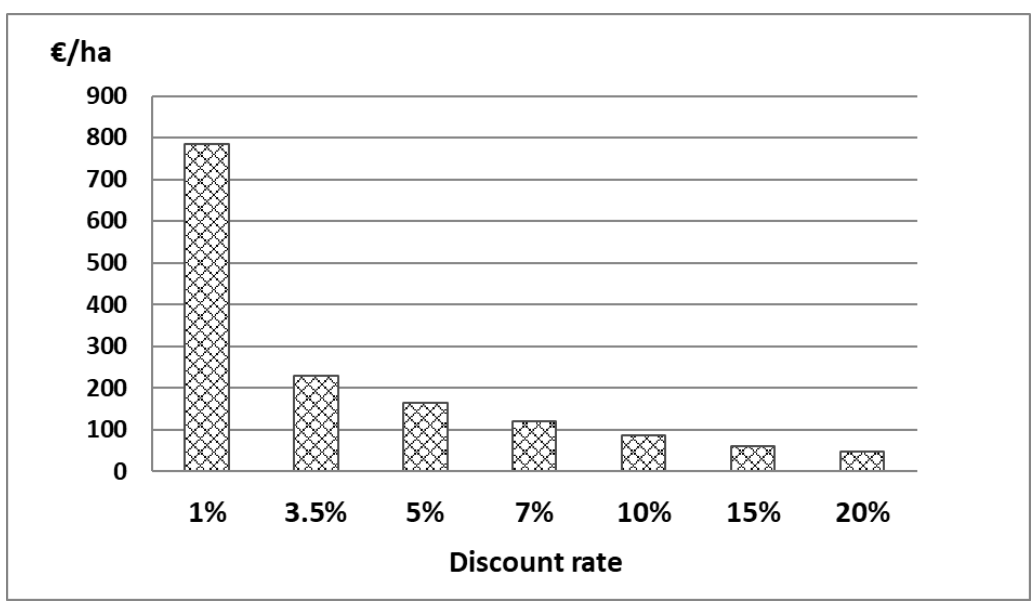

Figure 3. The average marginal value to farmers of conserving their soil natural capital is based on an assumed $1 \%$ relative change in the average stock of soil natural capital in the study region today. The increasing discount rate implies that future profits are increasingly down-valued by the farmer, and hence reduce the present value of their soil capital.

\subsection{Regional Level}

The first step towards valuing changes in flows of public-good ecosystem services is to quantify and aggregate these at a relevant spatial scale such as the region we focus on here, which is done using the AgriPoliS model and the indicators of public-good ecosystem services.

The impacts of the three grass scenarios on the region's total soil organic carbon stock, annual nitrogen emissions to the Baltic Sea, nitrogen fertilizer input and profits, as well as the average hectare yield of winter wheat are presented in Table 3 compared to the reference scenario at the end of the simulation period (2016). As expected, public-good services in the form of carbon storage increase, and nutrient emissions and fertilizer $\mathrm{N}$ input decrease substantially with the proportion of grass in the rotation. Initially, regional profits also decrease substantially, e.g., by $18 \%$ in the $25 \%$ grass scenario, due to the large opportunity cost (i.e., forgone income) of lost crop production. However, over time, the improvements in soil productivity brought about by the improvements in supporting ecosystem services implied by the grass scenarios, result in this impact diminishing over time. By the end of the simulation period, i.e., in 2036, only a small reduction in total profits (i.e., $\sim 1 \%$ ) is predicted. This implies that farmers' costs of conserving soil carbon represent in fact investments in soil natural capital, which are repaid over time through the associated increase in soil productivity. Together, these results indicate the potential for investments in soil natural capital today to balance environmental concerns with future food production needs on the one hand, and farmers' livelihoods on the other.

Table 3. Changes in the region's total soil organic carbon stock, annual nitrogen emissions to the Baltic Sea, nitrogen fertilizer input, and farm profit in 2036 compared to the reference scenario in 2036, as well as changes in the average hectare yield of winter wheat.

\begin{tabular}{|c|c|c|c|c|c|}
\hline Scenario and Reference Year & $\begin{array}{l}\text { Carbon } \\
\text { Stock }\end{array}$ & $\begin{array}{l}\text { Annual N } \\
\text { Emissions }\end{array}$ & $\begin{array}{l}\text { Fertilizer N } \\
\text { Input }\end{array}$ & $\begin{array}{l}\text { Regional } \\
\text { Profit }\end{array}$ & $\begin{array}{l}\text { Average } \\
\text { Yield * }\end{array}$ \\
\hline Baseline level in 2016 & $10.9 \times 10^{6} \mathrm{t}$ & $4.2 \times 10^{3} \mathrm{t}$ & $22.5 \times 10^{3} \mathrm{t}$ & $164 \times 10^{6} €$ & $7.90 \mathrm{t}$ \\
\hline Level in reference scenario in 2036 & $9.8 \times 10^{6} \mathrm{t}$ & $4.5 \times 10^{3} \mathrm{t}$ & $24.0 \times 10^{3} \mathrm{t}$ & $146 \times 10^{6} €$ & $7.58 \mathrm{t}$ \\
\hline $\begin{array}{l}\text { Change 2016-2036 in reference } \\
\text { scenario }\end{array}$ & $-10.0 \%$ & $6.2 \%$ & $6.4 \%$ & $-11 \%$ & $-4.0 \%$ \\
\hline \multicolumn{6}{|c|}{ Percentage difference in grass scenarios compared to levels in the reference scenario in 2036} \\
\hline 5\% Grass & $1.5 \%$ & $-2.8 \%$ & $-5.8 \%$ & $-0.73 \%$ & $0.7 \%$ \\
\hline $15 \%$ Grass & $4.7 \%$ & $-8.3 \%$ & $-17.1 \%$ & $-0.41 \%$ & $2.0 \%$ \\
\hline $25 \%$ Grass & $7.8 \%$ & $-13.7 \%$ & $-28.4 \%$ & $-0.98 \%$ & $3.4 \%$ \\
\hline
\end{tabular}

Source: Results of AgriPoliS simulations. ${ }^{*}$ The average yield for winter wheat is shown for illustrative purposes as it is the predominant crop but yields for the other crops are affected in identical directions. 
The simulated changes in agricultural productivity also imply a change in the underlying value of the region's soil natural capital and hence future food security. All three alternative scenarios generated a higher value of the region's soil natural capital than the reference scenario and over the range of tested discount rates (Figure 4): the assumed social rate of discount of 3.5\%, a lower (1\%) rate and higher (5\%) rate. As the scenario with $25 \%$ grass maintained the highest levels of supporting ecosystem services as indicated by SOC content, it also conserved the highest stock of soil natural capital and hence contribution to future food security. As expected, the magnitude of the valuation of the change in future food security is highly sensitive to the choice of discount rate. To put these valuations in perspective, the current market value of arable land in the region is around $23,000 €$ ha $^{-1}$ [64], implying potentially substantial changes in farmers' wealth due to changes in supporting ecosystem services.

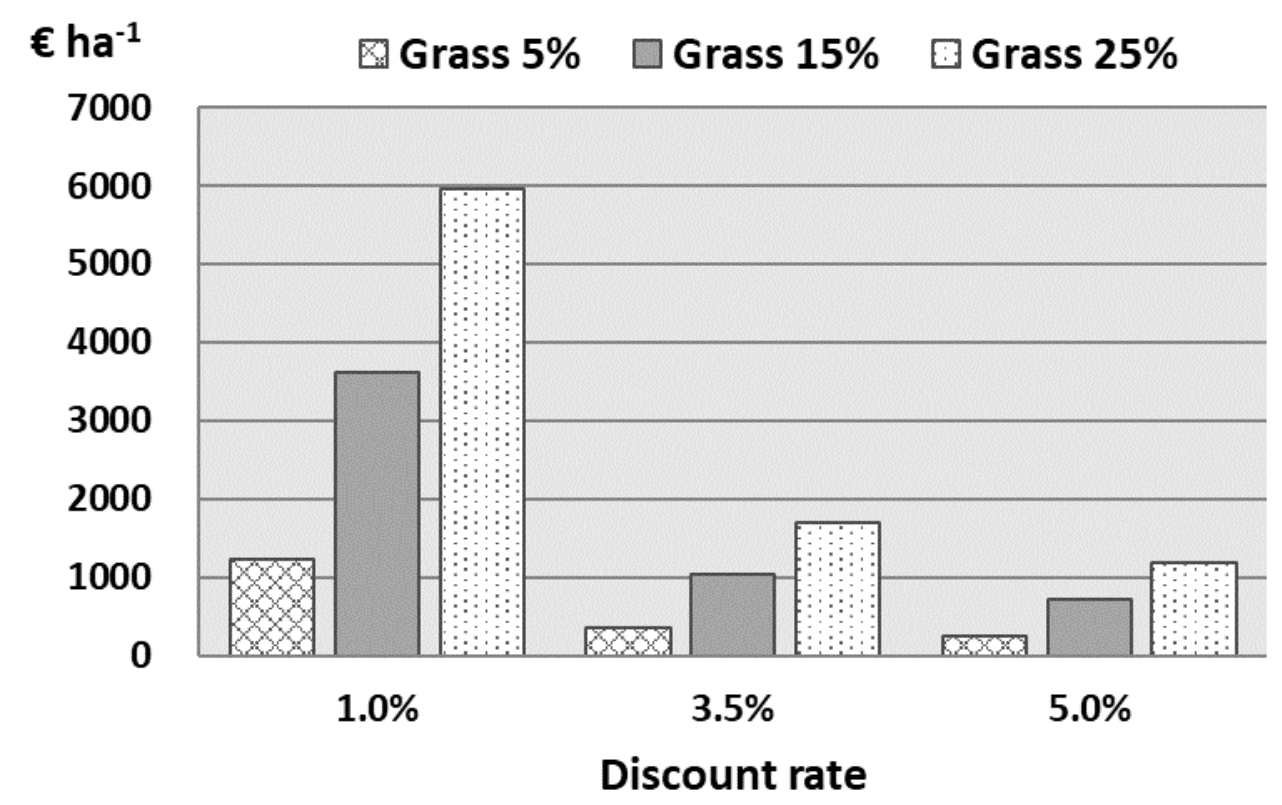

Figure 4. Average changes in the value of the region's stock of soil natural capital compared to the reference scenario for a range of discount rates over the 20 year evaluation period.

\subsection{National Level}

The simulated changes in the indicators of public-good ecosystem services compared to the reference scenario, were converted to their monetary values using both the low and high valuations of public goods (Table 4). Since each of the alternative management scenarios resulted in higher levels of public-good services over the evaluation period compared to the reference scenario, they also result in higher values of public-good services. The higher the proportion of grass in the alternative management scenario and assumed marginal valuation, low or high scenario, the higher the valuation of the impact on each public-good service.

The large differences between the low and high valuations of public-good services reflect the uncertainty associated with the marginal valuations of these services, which is why we perform the evaluation on societal welfare below considering this uncertainty.

Finally, to evaluate the net impact of the grass scenarios on societal welfare we sum, according to Equation (11), the net present values of the costs and benefits to farmers of implementing the scenarios (farmer profits) with the additional benefits to society in the form of the increased levels of public-good services (Table 5). Although farmers benefit from reduced costs for fertilizers and higher optimal yields over time, the opportunity costs of increasing the area of grass in the crop rotation are higher, hence the net negative impact on farmers' profits. The valuation of the change in farmers' soil natural capital is not included in the calculation of farmers' profits (as reasoned above) but is included in the impact on future food security. 
Table 4. Impacts on societal welfare of increased flows of public-good ecosystem services compared to the reference scenario (present values calculated in $€$ millions over the 20 year simulation period and using a social rate of discount of $3.5 \%$ ).

\begin{tabular}{ccccccccc}
\hline \multirow{2}{*}{$\begin{array}{c}\text { Grass } \\
\text { Scenario }\end{array}$} & \multicolumn{2}{c}{ Carbon Storage } & \multicolumn{2}{c}{ GHG Emissions } & \multicolumn{2}{c}{ N Emissions } & \multicolumn{2}{c}{ Total } \\
\cline { 2 - 9 } & \multicolumn{2}{c}{ P-G Valuations * } & \multicolumn{2}{c}{ P-G Valuations } & \multicolumn{2}{c}{ P-G Valuations } & \multicolumn{2}{c}{ P-G Valuations } \\
\cline { 2 - 9 } & Low & High & Low & High & Low & High & Low & High \\
\hline $5 \%$ & 2.4 & 45.2 & 0.4 & 18.0 & 0.4 & 7.0 & 3.2 & 70.2 \\
$15 \%$ & 7.2 & 136.5 & 1.3 & 53.8 & 1.1 & 20.9 & 9.6 & 211.1 \\
$25 \%$ & 12.0 & 227.6 & 2.1 & 87.9 & 1.8 & 34.5 & 15.9 & 350.0 \\
\hline
\end{tabular}

* P-G refers to the assumed marginal valuations of the public-good ecosystem services.

Table 5. Impacts on societal welfare of the alternative soil management scenarios (net present values over 20 years in $€$ millions and using a discount rate of $3.5 \%$ ).

\begin{tabular}{|c|c|c|c|c|c|c|}
\hline \multirow{2}{*}{ Impacts on Welfare } & \multicolumn{3}{|c|}{ Low P-G Valuations * } & \multicolumn{3}{|c|}{ High P-G Valuations } \\
\hline & $5 \%$ & $15 \%$ & $25 \%$ & $5 \%$ & $15 \%$ & $25 \%$ \\
\hline Public-good ecosystem services & 3.2 & 9.6 & 15.9 & 70.2 & 211.1 & 350.0 \\
\hline Future food security & 25.2 & 74.9 & 123.7 & 25.2 & 74.9 & 123.7 \\
\hline Farmers' profits & -21.5 & -75.3 & -132.7 & -21.5 & -75.3 & -132.7 \\
\hline Net change in societal welfare & 6.9 & 9.2 & 6.9 & 73.9 & 210.8 & 341.0 \\
\hline
\end{tabular}

* P-G refers to the assumed marginal valuations of the public-good ecosystem services.

The net effect on societal welfare is positive in all scenarios and for all valuations of public good services (Table 5). In particular a substantial trade-off emerges between future food security or future generations' welfare, and current-generation farmers' profits. Applying the low valuations of public good services and higher rates of discounts favors the production of private-good ecosystem services over provisioning of public-good services. Consequently, farmers are not likely to be optimizing their soil management decisions from Swedish society's perspective, implying a need for improved governance.

\section{Discussion}

We have developed and applied a roadmap for evaluating the contribution of both private- and public-good ecosystem services generated by agricultural soils to societal welfare. Our results provide evidence that the marginal value of conserving soil natural capital and attendant ecosystem services is much greater for society than for individual farmers (Table 5). However, we also found that conserving soil natural capital would benefit farmers in the future, through higher yields and lower fertilizer needs, as expected [65]. The dilemma for current farmers is that it can be very costly for them to adopt soil-friendly alternative practices [66], such as the grass measure evaluated here. Indeed, our results indicate that farmers could not be expected to implement such effective measures voluntarily, even if informed of the long-term benefits, because the net present value to them of adopting the grass measure was negative (in all scenarios). Other studies also identify high societal benefits of ameliorating the ongoing degradation of soil ecosystem services [22], but recognize that the relatively high costs to farmers constitute a considerable barrier to improving soil management [67]. Thus, our results corroborate the general finding from the literature that substantial trade-offs exist between farmers' current incomes and the provisioning of public-good soil ecosystem services, particularly climate benefits [68]. Yet, our study indicates that it would increase societal welfare if farmers were to implement measures to restore soil ecosystem services, despite the high costs to them. This implies that a serious market failure exists, which requires a policy response to coordinate the efficient management of soil natural capital and attendant ecosystem services [69]. 
It is possible for us to come to this conclusion, because we converted the simulated changes in the different biophysical indicators of soil natural capital and public-good ecosystem services (that are otherwise incomparable metrics) to a common unit of value, willingness-to-pay (WTP). Our approach also makes explicit who the potential gainers and losers are of implementing conservation measures. The former being in this case the general public (now and in the future) and future farmers (thanks to higher soil productivity in the future); and the losers, present-day farmers due to the high costs to them of adopting soil-friendly measures.

Nevertheless, some argue that monetary valuation and BCA are inappropriate for evaluating natural capital $[70,71]$. Various other frameworks have been suggested, but we contend that these lack the objectivity and internal consistency of BCA [72], as BCA allows for comparing changes in flows of ecosystem services in comparable units (citizens' willingness-to-pay), reveals the distribution of costs and benefits among different groups, and explicitly considers time preferences. The ultimate strength of BCA is that it can provide guidance to policymakers on how limited budgets should be allocated to maximize societal welfare given other worthwhile uses for these resources, e.g., education, health care, combating poverty and climate change. However, in practice BCA is not usually the sole basis for public decisions [28], and particularly due to the complexity of soil ecosystems, it should be complemented with other frameworks and indicators [21] because sufficient information to fully value ecosystem services will not usually be available.

Additionally, the valuations of public-good services used here are uncertain, because they are based on hypothetical studies or political decisions [73]. In particular, our valuation of climate services is substantial and crucial for our conclusions. Still, even our very conservative or low valuation resulted in all grass measures passing the benefit-cost test. Nevertheless, one may well question the reliability of nonmarket valuations. Our valuation of climate benefits is based on the Swedish carbon tax on petrol. It was introduced in 1991 at a rate of 250 SEK per $t \mathrm{CO}_{2} \mathrm{e}$ and has been successively increased to its current rate of 1180 SEK. We argue that since this tax rate has emerged from the Swedish parliament as a product of political deliberation and has been in place for almost three decades, that it is a stable reflection of Swedish citizens' preferences. Since climate change is a global problem, the benefits of reducing emissions are also identical between sectors. Hence, there is no reason to value the climate services of soils differently to that of reducing the burning of fossil fuels. Further, we also potentially undervalue the contribution of soils to public-good ecosystem services through omission of other public-good services. For instance, nutrient losses from agriculture also affect the quality of inland waters; however, due to lack of relevant valuation studies we ignore this potential impact, which implies our evaluation risks undervaluing the contribution of nutrient retention services to societal welfare.

Overall, our study implies that current market outcomes are not likely to be generating optimal levels of soil ecosystem services. To remedy such a pervasive market failure innovative governance is needed to address the underlying lack of incentives faced by farmers to consider the value of public-good ecosystem services in their management decisions [10]. A promising way forward for overcoming measurement problems and realizing evidence-based policy schemes is through modelling the impacts of different management practices on indicators of soil ecosystem services [74].

We believe that a valuation method based on indicators of soil natural capital and ecosystem services is necessary for influencing soil management decisions at multiple levels. From a decision-maker's perspective, it is crucial, at some stage, that the complexities of the soil ecosystem can be boiled down to indicators of changes in levels of soil ecosystem services that are relevant to their goals. For farmers, such indicators would be those that can be related to impacts on their wealth, and for policy-makers those indicators would concern societal welfare [75]. This is because changes in the stock of soil natural capital and levels of ecosystem services are not easily observable, but usually occur insidiously. A soil-health indicator that is straightforward to understand will naturally increase its likelihood of acceptance as a basis for making decisions. In this study we use changes in soil organic carbon content as an indicator of changes in soil natural capital affecting agricultural productivity and 
climate benefits [19], but if it is impractical one could use other indicators correlated to it as a proxy for soil health [76]. Our point is that one needs indicators that are intuitive for decision-makers and that can be measured or at least approximated through modelling.

In closing, we wish to point out that our study has not considered the implications of uncertainty about the future for the value of conserving soil natural capital and attendant ecosystem services. It has been shown that soil natural capital also has insurance or resilience value related to uncertainty about the future, particularly the threats posed by climate change $[77,78]$. By stabilizing the system, practices that conserve soil natural capital can provide self-protection (insurance) against variability in flows of soil ecosystem services, where the additional costs of management can be construed as the premium for securing this insurance [79]. Additionally, conserving biodiversity also maintains options related to uncertain future needs and preferences, and this flexibility also has value, an option value [80]. Considering these insurance values implies that investing in soil natural capital provides benefits to farmers and society, in excess of the benefits quantified here. How to quantify and communicate insurance value to decision-makers as well as developing evidence-based policy schemes are important avenues for future research.

Supplementary Materials: The following are available online at http://www.mdpi.com/2071-1050/11/19/5285/s1. Figure S1: Plots of the production functions for the four main crops in the region, Table S1: Areas of annual crops and average SOC content in the study region, Table S2: Estimated coefficients of production functions, Table S3: Estimation results for the spring barley production function, Table S4: Estimation results for sugar beet production function, Table S5: Approximation of average soil bulk density and carbon stock per ha of arable land in the study region, Table S6: Economic data used to parameterize the farmers' profit function.

Author Contributions: All authors have contributed substantially to this article, in particular regarding: Conceptualization, M.V.B., K.H. and F.W.; Methodology, M.V.B., K.H., J.H. and F.W.; Software, M.V.B. and J.H.; Validation, M.V.B., K.H., J.H. and F.W.; Formal Analysis, M.V.B., J.H. and F.W.; Writing-Original Draft Preparation, M.V.B.; Writing-Review \& Editing, M.V.B., K.H., J.H. and F.W.; Funding Acquisition, K.H.

Funding: This research was funded by Naturvårdsverket (Swedish EPA) to Hedlund (VESA). The research presented in this paper is a contribution to the strategic research area Biodiversity and Ecosystems in a Changing Climate, BECC.

Acknowledgments: We are grateful for comments from three anonymous reviewers and a scientific editor that have helped us to improve this article.

Conflicts of Interest: The authors declare no conflict of interest. The funders had no role in the design of the study; in the collection, analyses, or interpretation of data; in the writing of the manuscript, or in the decision to publish the results.

\section{References}

1. Barrios, E. Soil biota, ecosystem services and land productivity. Ecol. Econ. 2007, 64, 269-285. [CrossRef]

2. Haygarth, P.M.; Ritz, K. The future of soils and land use in the UK: Soil systems for the provision of land-based ecosystem services. Land Use Policy 2009, 26, S187-S197. [CrossRef]

3. Adhikari, K.; Hartemink, A.E. Linking soils to ecosystem services-A global review. Geoderma 2016, 262, 101-111. [CrossRef]

4. Cassman, K.G.; Dobermann, A.; Walters, D.T.; Yang, H. Meeting Cereal Demand While Protecting Natural Resources and Improving Environmental Quality. Ann. Rev. Environ. Resour. 2003, 28, 315-358. [CrossRef]

5. Foley, J.A.; Ramankutty, N.; Brauman, K.A.; Cassidy, E.S.; Gerber, J.S.; Johnston, M.; Mueller, N.D.; O'Connell, C.; Ray, D.K.; West, P.C.; et al. Solutions for a cultivated planet. Nature 2011, 478, 337-342. [CrossRef] [PubMed]

6. Bommarco, R.; Kleijn, D.; Potts, S.G. Ecological intensification: Harnessing ecosystem services for food security. Trends Ecol. Evol. 2013, 28, 230-238. [CrossRef]

7. Lal, R. Managing Soils and Ecosystems for Mitigating Anthropogenic Carbon Emissions and Advancing Global Food Security. Bioscience 2010, 60, 708-721. [CrossRef]

8. Shortle, J.; Horan, R.D. Nutrient Pollution: A Wicked Challenge for Economic Instruments. Water Econ. Policy 2017, 3, 1650033. [CrossRef] 
9. Tilman, D.; Cassman, K.G.; Matson, P.A.; Naylor, R.; Polasky, S. Agricultural sustainability and intensive production practices. Nature 2002, 418, 671-677. [CrossRef] [PubMed]

10. Bartkowski, B.; Hansjürgens, B.; Möckel, S.; Bartke, S. Institutional Economics of Agricultural Soil Ecosystem Services. Sustainability 2018, 10, 2447. [CrossRef]

11. Robinson, D.A.; Fraser, I.; Dominati, E.J.; Davíðsdóttir, B.; Jónsson, J.O.G.; Jones, L.; Jones, S.B.; Tuller, M.; Lebron, I.; Bristow, K.L.; et al. On the Value of Soil Resources in the Context of Natural Capital and Ecosystem Service Delivery. Soil Sci. Soc. Am. J. 2014, 78, 685-700. [CrossRef]

12. Banwart, S. Save our soils. Nature 2011, 474, 151-152. [CrossRef] [PubMed]

13. Daily, G.C.; Polasky, S.; Goldstein, J.; Kareiva, P.M.; Mooney, H.A.; Pejchar, L.; Ricketts, T.H.; Salzman, J.; Shallenberger, R. Ecosystem services in decision making: Time to deliver. Front. Ecol. Environ. 2009, 7, 21-28. [CrossRef]

14. McBratney, A.; Field, D.J.; Koch, A. The dimensions of soil security. Geoderma 2014, 213, 203-213. [CrossRef]

15. Doran, J.W. Soil health and global sustainability: Translating science into practice. Agric. Ecosyst. Environ. 2002, 88, 119-127. [CrossRef]

16. Adhikari, B.; Nadella, K. Ecological economics of soil erosion: A review of the current state of knowledge. Ann. N. Y. Acad. Sci. 2011, 1219, 134-152. [CrossRef]

17. Dominati, E.; Patterson, M.; Mackay, A. A framework for classifying and quantifying the natural capital and ecosystem services of soils. Ecol. Econ. 2010, 69, 1858-1868. [CrossRef]

18. Robinson, D.A.; Lebron, I. On the natural capital and ecosystem services of soils. Ecol. Econ. 2010, 70, 137-138. [CrossRef]

19. Albizua, A.; Williams, A.; Hedlund, K.; Pascual, U. Crop rotations including ley and manure can promote ecosystem services in conventional farming systems. Appl. Soil Ecol. 2015, 95, 54-61. [CrossRef]

20. Haddaway, N.R.; Hedlund, K.; Jackson, L.E.; Kätterer, T.; Lugato, E.; Thomsen, I.K.; Jørgensen, H.B.; Söderström, B. What are the effects of agricultural management on soil organic carbon in boreo-temperate systems? Environ. Evid. 2015, 4, 1-29. [CrossRef]

21. Brady, M.V.; Hedlund, K.; Cong, R.-G.; Hemerik, L.; Hotes, S.; Machado, S.; Mattsson, L.; Schulz, E.; Thomsen, I.K. Valuing Supporting Soil Ecosystem Services in Agriculture: A Natural Capital Approach. Agron. J. 2015, 107, 1809-1821. [CrossRef]

22. Plaas, E.; Meyer-Wolfarth, F.; Banse, M.; Bengtsson, J.; Bergmann, H.; Faber, J.; Potthoff, M.; Runge, T.; Schrader, S.; Taylor, A. Towards valuation of biodiversity in agricultural soils: A case for earthworms. Ecol. Econ. 2019, 159, 291-300. [CrossRef]

23. Dominati, E.; Mackay, A.; Green, S.; Patterson, M. A soil change-based methodology for the quantification and valuation of ecosystem services from agro-ecosystems: A case study of pastoral agriculture in New Zealand. Ecol. Econ. 2014, 100, 119-129. [CrossRef]

24. Graves, A.R.; Morris, J.; Deeks, L.K.; Rickson, R.J.; Kibblewhite, M.G.; Harris, J.A.; Farewell, T.S.; Truckle, I. The total costs of soil degradation in England and Wales. Ecol. Econ. 2015, 119, 399-413. [CrossRef]

25. Baveye, P.C.; Baveye, J.; Gowdy, J. Soil "Ecosystem" Services and Natural Capital: Critical Appraisal of Research on Uncertain Ground. Front. Environ. Sci. 2016, 4, 41. [CrossRef]

26. Zhou, Z.; Palmborg, C.; Ericson, L.; Dryler, K.; Lindgren, K.; Bergkvist, G.; Parsons, D. A 60-years old field experiment demonstrates the benefit of leys in the crop rotation. Acta Agric. Scand. B Soil Plant Sci. 2019, 69, 36-42. [CrossRef]

27. Prade, T.; Kätterer, T.; Björnsson, L. Including a one-year grass ley increases soil organic carbon and decreases greenhouse gas emissions from cereal-dominated rotations-A Swedish farm case study. Biosys. Eng. 2017, 164, 200-212. [CrossRef]

28. Hanley, N.; Spash, C.L. Cost-Benefit Analysis and the Environment; Edward Elgar: Aldershot, UK, 1993.

29. Johansson, P.-O. An Introduction to Modern Welfare Economics; Cambridge University Press: Cambridge, UK, 1991.

30. Atkinson, G.; Bateman, I.; Mourato, S. Recent advances in the valuation of ecosystem services and biodiversity. Oxf. Rev. Econ. Policy 2012, 28, 22-47. [CrossRef]

31. SCB. Standard Yields for Yield Survey Districts, Counties and the Whole Country in 2013 (In Swedish, Normskördar för Skördeområden, Län och Riket 2013); Statistics Sweden: Örebro, Sweden, 2013.

32. HS. Soil Organic Carbon Database; The Rural Economy and Agricultural Societies (in Swedish Hushållningssällskapen): Borgeby, Sweden, 2017. 
33. Luo, Z.; Wang, E.; Sun, O.J. Soil carbon change and its responses to agricultural practices in Australian agro-ecosystems: A review and synthesis. Geoderma 2010, 155, 211-223. [CrossRef]

34. Blair, N.; Faulkner, R.D.; Till, A.R.; Körschens, M.; Schulz, E. Long-term management impacts on soil C, N and physical fertility: Part II: Bad Lauchstadt static and extreme FYM experiments. Soil Tillage Res. 2006, 91, 39-47. [CrossRef]

35. Alvarez, R. A review of nitrogen fertilizer and conservation tillage effects on soil organic carbon storage. Soil Use Manag. 2005, 21, 38-52. [CrossRef]

36. Thomsen, I.K.; Christensen, B.T. Yields of wheat and soil carbon and nitrogen contents following long-term incorporation of barley straw and ryegrass catch crops. Soil Use Manag. 2004, 20, 432-438. [CrossRef]

37. Nelson, E.; Mendoza, G.; Regetz, J.; Polasky, S.; Tallis, H.; Cameron, D.R.; Chan, K.M.; Daily, G.C.; Goldstein, J.; Kareiva, P.M.; et al. Modeling multiple ecosystem services, biodiversity conservation, commodity production, and tradeoffs at landscape scales. Front. Ecol. Environ. 2009, 7, 4-11. [CrossRef]

38. McConnell, K.E.; Bockstael, N.E. Valuing the Environment as a Factor of Production. In Handbook of Environmental Economics; Mäler, K.-G., Vincent, J.R., Eds.; North-Holland: Amsterdam, The Netherlands; San Diego, CA, USA, 2005; Chapter 14, Volume 2.

39. Gollier, C. Pricing the Future: The Economics of Discounting and Sustainable Development; Princeton University Press: Princeton, UK, 2011.

40. Balmann, A. Farm-based modelling of regional structural change: A cellular automata approach. Eur. Rev. Agric. Econ. 1997, 24, 85-108. [CrossRef]

41. Happe, K.; Kellermann, K.; Balmann, A. Agent-based Analysis of Agricultural Policies: An Illustration of the Agricultural Policy Simulator AgriPoliS, its Adaptation and Behavior. Ecol. Soc. 2006, 11, 49. [CrossRef]

42. Brady, M.; Sahrbacher, C.; Kellermann, K.; Happe, K. An agent-based approach to modeling impacts of agricultural policy on land use, biodiversity and ecosystem services. Landsc. Ecol. 2012, 27, 1363-1381. [CrossRef]

43. Kellermann, K.; Happe, K.; Sahrbacher, C.; Balmann, A.; Brady, M.; Schnicke, H.; Osuch, A. AgriPoliS 2.1-Model Documentation; IAMO: Halle, Germany, 2008.

44. Hristov, J.; Brady, M.V.; Dong, C.; Sahrbacher, A.; Sahrbacher, C. Representation of the Scanian Regions GMB and GSS in AgriPoliS and Recent Model Extensions; AgriFood Economics Centre: Lund, Sweden, 2017; p. 34. Available online: https://www.agrifood.se/publication.aspx?fKeyID=1879 (accessed on 1 July 2019).

45. Höjgård, S.; Wilhelmsson, F. Produktion av Biogas Från Gödsel; AgriFood Economics Centre: Lund, Sweden, 2012.

46. Wulff, F.; Humborg, C.; Andersen, H.E.; Blicher-Mathiesen, G.; Czajkowski, M.; Elofsson, K.; Fonnesbech-Wulff, A.; Hasler, B.; Hong, B.; Jansons, V.; et al. Reduction of Baltic Sea Nutrient Inputs and Allocation of Abatement Costs Within the Baltic Sea Catchment. Ambio 2014, 43, 11-25. [CrossRef] [PubMed]

47. Simmelsgaard, S.E.; Djurhuus, J. An empirical model for estimating nitrate leaching as affected by crop type and the long-term N fertilizer rate. Soil Use Manag. 1998, 14, 37-43. [CrossRef]

48. Blombäck, K.; Johnsson, H.; Lindsjö, A.; Mårtensson, K.; Persson, K.; Schmieder, F. Leaching of Nutrients from Swedish Arable Land (In Swedish: Läckage av näringsämnen från svensk åkermark för år 2009 beräknat med PLC5-metodik); Swedish Meteorological and Hydrological Institute: Norrköping, Sweden, 2011.

49. Simmelsgaard, S.E. The Effect of Crop, N-Level, Soil Type and Drainage on Nitrate Leaching from Danish Soil. Soil Use Manag. 1998, 14, 30-36. [CrossRef]

50. Brunell, J.T.; Gustavsson, H.; Dahné, J.; Alavi, G. Retention Calculated with SMEDHYPE (In Swedish: Retention beräknad med SMEDHYPE); Swedish Meteorological and Hydrological Institute: Norrköping, Sweden, 2016.

51. Sunderland, T.C.H. Food security: Why is biodiversity important? Int. For. Rev. 2011, 13, 265-274. [CrossRef]

52. Brunstad, R.J.; Gaasland, I.; Vårdal, E. Multifunctionality of Agriculture: An Inquiry into the Complementarity between Landscape Preservation and Food Security. Eur. Rev. Agric. Econ. 2005, 32, 469-488. [CrossRef]

53. Bostedt, G.; Löfgren, S.; Innala, S.; Bishop, K. Acidification Remediation Alternatives: Exploring the Temporal Dimension with Cost Benefit Analysis. Ambio 2010, 39, 40-48. [CrossRef] [PubMed]

54. Crost, B.; Traeger, C.P. Optimal $\mathrm{CO}_{2}$ mitigation under damage risk valuation. Nat. Clim. Chang. 2014, 4, 631. [CrossRef]

55. Government Offices of Sweden Sweden's Carbon Tax [Online]. 2009. Available online: https://www. government.se/government-policy/taxes-and-tariffs/swedens-carbon-tax/ (accessed on 4 July 2019). 
56. Ahtiainen, H.; Artell, J.; Czajkowski, M.; Hasler, B.; Hasselström, L.; Huhtala, A.; Meyerhoff, J.; Smart, J.C.R.; Söderqvist, T.; Alemu, M.H.; et al. Benefits of meeting nutrient reduction targets for the Baltic Sea-A contingent valuation study in the nine coastal states. J. Environ. Econ. Policy 2014, 3, 278-305. [CrossRef]

57. AgriWise Agriwise: Data Book for Production Planning and Regional Enterprise Budgets. Available online: http://www.agriwise.org/ (accessed on 26 October 2017). (In Swedish)

58. De Nocker, L.; Vermoote, S.; Heck, T. Valuation of environmental impacts based on preferences revealed in political negotiations and public referenda. In New Elements for the Assessment of External Costs from Energy Technologies. NewExt Project: Final Report to the European Commission, DG Research, Technological Development and Demonstration (RTD); Friedrich, R., Ed.; University of Stuttgart: Stuttgart, Germany, 2004; pp. 119-148.

59. Warren, R. Optimal carbon tax doubled. Nat. Clim. Chang. 2014, 4, 534-535. [CrossRef]

60. Carbon Pulse. EU Market: EUAs Stumble Despite Strong Auction, with Observers Mixed on Next Move; Carbon Pulse: London, UK, 2016.

61. HELCOM. State of the Baltic Sea-Second HELCOM Holistic Assessment 2011-2016; HELCOM: Helsinki, Finland, 2018.

62. Ahlvik, L.; Ahtiainen, H. Marginal Benefits of Reducing Nutrient Loads to the Baltic Sea; MTT Agrifood Research Finland \& City of Helsinki, EU Life+ Project CITYWATER-Benchmarking Water Protection in Cities: Helsinki, Finland, 2014.

63. Svensson, M.; Hultkrantz, L. Ekonomiska utvärderingar i svensk offentlig sektor-Likheter och skillnader. Ekonomisk Debatt 2014, 43, 40-50.

64. SCB. Agricultural Land Prices 2017; Statistics Sweden: Örebro, Sweden, 2018.

65. Oldfield, E.E.; Bradford, M.A.; Wood, S.A. Global meta-analysis of the relationship between soil organic matter and crop yields. Soil 2019, 5, 15-32. [CrossRef]

66. Nainggolan, D.; Hasler, B.; Andersen, H.E.; Gyldenkærne, S.; Termansen, M. Water Quality Management and Climate Change Mitigation: Cost-effectiveness of Joint Implementation in the Baltic Sea Region. Ecol. Econ. 2018, 144, 12-26. [CrossRef]

67. Poulton, P.; Johnston, J.; Macdonald, A.; White, R.; Powlson, D. Major limitations to achieving “4 per 1000 " increases in soil organic carbon stock in temperate regions: Evidence from long-term experiments at Rothamsted Research, United Kingdom. Glob. Chang. Biol. 2018, 24, 2563-2584. [CrossRef]

68. Amundson, R.; Biardeau, L. Opinion: Soil carbon sequestration is an elusive climate mitigation tool. Proc. Natl. Acad. Sci. USA 2018, 115, 11652-11656. [CrossRef]

69. Drechsler, M. The Impact of Fairness on Side Payments and Cost-Effectiveness in Agglomeration Payments for Biodiversity Conservation. Ecol. Econ. 2017, 141, 127-135. [CrossRef]

70. Sagoff, M. The quantification and valuation of ecosystem services. Ecol. Econ. 2011, 70, 497-502. [CrossRef]

71. Gómez-Baggethun, E.; Ruiz-Pérez, M. Economic valuation and the commodification of ecosystem services. Prog. Phys. Geogr. Earth Environ. 2011, 35, 613-628. [CrossRef]

72. Schwilch, G.; Bernet, L.; Fleskens, L.; Giannakis, E.; Leventon, J.; Marañón, T.; Mills, J.; Short, C.; Stolte, J.; van Delden, H.; et al. Operationalizing ecosystem services for the mitigation of soil threats: A proposed framework. Ecol. Indic. 2016, 67, 586-597. [CrossRef]

73. Mendelsohn, R. An Examination of Recent Revealed Preference Valuation Methods and Results. Rev. Environ. Econ. Policy 2019, 13, 267-282. [CrossRef]

74. Sidemo-Holm, W.; Smith, H.G.; Brady, M.V. Improving agricultural pollution abatement through result-based payment schemes. Land Use Policy 2018, 77, 209-219. [CrossRef]

75. Griffiths, B.S.; Römbke, J.; Schmelz, R.M.; Scheffczyk, A.; Faber, J.H.; Bloem, J.; Pérès, G.; Cluzeau, D.; Chabbi, A.; Suhadolc, M.; et al. Selecting cost effective and policy-relevant biological indicators for European monitoring of soil biodiversity and ecosystem function. Ecol. Indic. 2016, 69 (Suppl. C), 213-223. [CrossRef]

76. Bouma, J. Soil Security in Sustainable Development. Soil Syst. 2019, 3, 5. [CrossRef]

77. Cong, R.-G.; Hedlund, K.; Andersson, H.; Brady, M. Managing soil natural capital: An effective strategy for mitigating future agricultural risks? Agric. Syst. 2014, 129, 30-39. [CrossRef]

78. Cong, R.-G.; Termansen, M.; Brady, M.V. Managing soil natural capital: A prudent strategy for adapting to future risks. Ann. Oper. Res. 2017, 255, 439-463. [CrossRef] 
79. Baumgärtner, S.; Strunz, S. The economic insurance value of ecosystem resilience. Ecol. Econ. 2014, 101, 21-32. [CrossRef]

80. Bartkowski, B. Are diverse ecosystems more valuable? Economic value of biodiversity as result of uncertainty and spatial interactions in ecosystem service provision. Ecosyst. Serv. 2017, 24, 50-57. [CrossRef] 